\title{
Re-Shaping the Political Field One Visual Fragment at a Time: The Tunisian Conundrum
}

\author{
Giulia Montanari* and Javier Toscano** \\ *Monadenscience Research Collective, Berlin, Germany, g_montanari@posteo.de \\ **Technische Universität Chemnitz, Chemnitz, Germany, tosgue@yahoo.com
}

\begin{abstract}
The Internet has become a vigorous political field of interactions. Many of these interchanges - confrontations as well as encounters - rely on the weight of the image as a prominent communication tool. We are now used to loads of images flowing through the Internet's digital corridors, but the mainstreaming of this phenomenon has brought about singular possibilities for political developments based on emerging uses and interpretations. In a way, politicians have historically made use of images to sustain their agendas, but the forms, styles and circumstances available today have become a game-changing factor at certain critical moments. In this article, we explore the case of the Tunisian Revolution of 2011 as a clear case of an important shift in this tradition. Our interpretation brings to the fore the double-edged semiotic meaning of a particular image and its key significance within a particular political event.
\end{abstract}

Keywords: Politics of the Image, Visual Studies, Documentary Method, Visual Genres

\section{The Political Field of the Image: New Practices and Meanings}

The Internet has become a vigorous political field of interactions. One of the central aims of the political is performed here: the search to influence others. But we need to acknowledge this function in its wider sense. This means departing from a strict Lasswellian approach that asks how the digital arena is used, as well as by whom, for what purpose, addressed to which audience, bearing which content and having which effect (Lasswell 1950), so as to include more complex exchanges, contexts and practices, such as the mechanics of power structures, the material performance of data networks, the communicative tactics of social claims and the function of ideologies that are shaped and help shape the digital media arena in a wide array of forms - causal, stochastic or dialectical (Fuchs 2008; 2014). This means also that the Internet is no longer (if it ever was) the imaginary land of progressive activism and hacking paradises (Fuller 2003), a plain form of communication and entertainment, or a possible opposition network seeking to debunk a traditional form of politics based on (now) old-style mass-media and other communication formats (Hanke 2005). The Internet is a platform that is no stable medium in itself; it is a dynamic frame, an always-developing setting where the economic means of production have a hold; a shifting site of exchanges that, nevertheless, tends to favour standardised activities. ${ }^{1}$

${ }^{1}$ In this sense, the Internet follows the logic of what Anselm L. Strauss had already deemed by 1979 a social world with a spatial process. As he writes: "Beginnings aside, social worlds are always likely in the business of finding new or additional spaces; the splintering off of sub-worlds always brings the likelihood that new spaces will be sought, or indeed deemed necessary for the differentiated activity now envisioned." (Strauss 1979, 3). For Strauss, a social world follows a sort of organic process of discovering, maintaining, com- 
The early days of radical anarchy, libertarianism and experimenting seem to be over. It is a well-known fact: as the masses increasingly move along the Internet through mediated gates, portals and digital environments (which periodically offer the user a sense of extreme novelty and fascination), normalisation and control come increasingly to the fore (Deleuze 1992). But we have certainly experienced periods of transition where some crevices were indeed explored by dissident forces trying out new social configurations and paradigms. And some traces of those uses and experiments can still be examined in order to understand further implications and possible developments between digital technologies and the social structures where they appear, and to which they are connected. Usually, these traces account for "modes of operation or schemata of action" and do not tackle "directly the subjects (or persons) who are their authors or vehicles" (de Certeau 1984, xi). But in some special circumstances, when this dialectical dynamic has moved ahead with some sort of awareness, when it has acknowledged what was politically at stake, the discursive economies of scale or the deep antagonisms underlying the social structure (Walker 2016, 112), small groups have assembled to produce, as it were, symptoms and indexes, tactical shifts, or what we could deem - with a cautious and critical optimism - a certain strategical dialectic able to affect the inertial course of everyday rituals, their programs and lineal causations: an event. ${ }^{2}$

The initial stage of the Arab Spring movement brought one of those moments on the scene, with an intense confrontation between society and political elites, and a series of consequences on the forms by which we understand politics and the political field. Many in the West were too hasty to understand those developments as prompted by Facebook or Twitter $^{3}$, two infamous portals through which an intense traffic surrounding those situations circulated. And yet, while those assumptions may seem to be reductive and misleading at times (and contribute to the sense of fascination that technology provides), Internet in fact, as a shifting ground, played a decisive

peting and abandoning: "Using technology as an example: the various technological processes include innovating, making trials, improving, servicing, adopting, diffusing, promoting, borrowing, adapting, regulating" (Ibid., 8).

${ }^{2}$ Following Arendt, an event is a beginning, and as such, one of the quintessential elements of the political (Arendt 1997, 64). This philosopher explains thus why this fascination with the new is key for classical revolutionaries (Arendt 1990/1963). Of course, Arendt's conception is influenced by the development of a specific element on Heidegger's thinking the Ereignis (Heidegger 1989). But the configuring of an event is far from being a core notion for contemporary political theory. It has been understood as a moment of opportunity from Lucretius' clinamen and the Epicurean school onwards (Lucretius 1963; Nichols 1976), and left its imprint on the Existentialism of Kierkegaard and Sartre. (Cf. a good outlook from different authors in Vatter and Ruiz Stull, 2011). Lately, the understanding of an event came into the study of statisticians such as Nassim Nicholas Taleb (2007), with sounding results for the financial and political systems of our time.

${ }^{3}$ The media were probably fascinated with a phenomenon that reflected upon their own function, or were too eager to find simple explanations. Even actors taking part in the events would report on them with a certain awe. An example is found in Kassim (2012). For a critical assessment on these approaches, see Morozov (2012). Investigating the uprisings in Egypt in 2011, the Indignados movement in Spain and Occupy Wall Street in the US, Gerbaudo cautiously argues instead that Twitter was being used to coordinate the protest's choreography $(2012,44)$, which still had to be conducted "on the ground" and did not constitute a new political space in itself. 
role in the set of revolts that were aggregated under that name. ${ }^{4}$ As Etling et al. argued on the brink of those social uprisings, "the internet [could] empower political movements in the region, since it [provided] an infrastructure for expressing minority points of view, breaking gatekeeper monopolies on public voice, lowering barriers to political mobilization (even if symbolic), and building capacity for bottom-up contributions to the public agenda." $(2010,10)$. As a dynamic platform, the Internet provided an opportunity in various ways, but mainly by helping media communities to learn from each other along different geographic locations, highlighting the symbioses between mass- and online-media, or by linking digital activism and cyber-journalism (what came to be known as a new form of citizen-journalism ${ }^{5}$, where anyone could become a field reporter) with offline, traditional activism. In all these interactions and exchanges, actors on all sides - but especially citizens coming for the first time into its grip - became increasingly aware of the potential of the image as a resistance tool. Under a state of urgency, ordinary people 'became the media', in order to transmit ongoing stories that other people could incorporate into a wider context. And for that aim, images appeared to be faster, more trenchant, more effective.

With the development of smartphones and their built-in photo and video cameras, everyone has become a potential social producer of images, which can then be mobilised as political devices. However brief, the Arab Spring turned out to be an experimental episode for these implementations. As a matter of fact, the Arab uprisings coincided with a technological progression: the first mobile phone with video capabilities had been introduced on the market barely in 1999 in Japan (Yegulalp 2012). ${ }^{6}$ These new portable devices for image production were accompanied by an emerging narrative and a proto-mythical stance, best exemplified by films such as The Blair Witch Project, also from 1999: low-tech as bringing us to the brink of the real (Banash 1999). In 2005, YouTube emerged as a multi-purpose, all-encompassing videoarchive, guaranteeing thus an extensive diffusion of videos; by 2010 , the world-wide number of mobile phones with integrated cameras totalled more than a billion (The Economist 2010). Since most of these devices produced low-quality images and videos, we witnessed the rise of the murky, blurry and shaky mobile-phone image as the new aesthetic for the 'authentic' during the last decade. In other words, the image connotations of the 'real', the 'authentic', the 'spontaneous' and the 'documental' were hinged together as a result of material practices of communication, as supported on new image capabilities added to cell-phone hardware. The image (still or moving) that anybody could take and upload to the web had turned into the node of emergence of the "truth" within a given event (Steyerl 2009; Lucendo 2010; Cardoso Pereira and Harcha 2014), particularly if that event appeared to have a social significance, as is the case with a political uprising. Along Internet networks - accessible through smartphones in a wider scale from the middle 00s onwards - where the po-

${ }^{4}$ And that includes the social movements in Tunisia, Egypt, Libya, Syria or Bahrain, mainly, with resonances in other Arab countries.

${ }^{5}$ If engaged journalism can be thought of as a form of conveying truth through compelling and investigative storytelling, citizen journalism relies more on the immediate transmission of circumstances that are important on the context where that individual is inscribed. (For a general outlook on the notion of cyber-journalism, see Allan 2009; a specific approach to the Arab Spring, in Khamis and Vaughn 2011.)

${ }^{6}$ Japanese smartphones - mobile personal computers with an operating system integrated into cell phones - were introduced in 1999 by the firm NTT DoCoMo, but were not widely available in the West or elsewhere (Budmar 2012), where their popularity surged only after the introduction of Apple's iPhone in 2007. 
litical aim decisively implies the search to influence others, the reference to symbols of 'truth' became a priceless tool for bolstering conviction, empathy and engagement. In this sense, the image had acquired - not only through its semiotic structure and its social significance, but also through its capability for wide-spread dissemination - an unrivalled value as a political asset.

Having this theoretical framework in mind, we will now turn to a deeper analysis of a picture that was originally distributed in a very traditional manner (it was handed out to the press by the Tunisian government after a hospital visit by President Ben Ali in 2010) but soon made its (in)famous way through different media channels with unexpected consequences. We will argue that this picture acquired a meaning of its own, since it mirrored almost perfectly the core of a social problem at the time and had a specific effect in demarcating existing conflict lines. To do so, we are going to show the implicit structure of the image by using the documentary method of image analysis (which we will discuss more extensively in the beginning of the empirical Chapter 3 ). In the course of the investigation that follows, we are also going to present the 'hospital visit' as a specific political genre that produces peculiar intentional visual material. Out of these analytic demarcations, the difference between what an image ought to tell the public (production of 'reality'), and what it actually reveals (perceived objective reality) will become clear and will be able to provide conclusive reasons on why this photographic object gained the significance it did.

\section{The Tunisian Case}

Within the Arab Spring narrative, the first of the Arab countries to be shaken by a new political experience with the image was Tunisia. Mohamed Bouazizi set himself on fire as a form of protest against the government bureaucracy in the town of Sidi Bouzid, in Tunisia, on 17 December 2010. This case, which produced no clear visual evidence, sparked a national outcry almost hours after it occurred. ${ }^{7}$ However, it was not the act itself, nor the symbolic stance alone of the man who so tragically died, that can be accountable for a country's revolution. The event was produced out of a set of social relations and a cultural-political context. Among them - and recognising that this description can only and always be partial - we can highlight the following:

1. The rareness of the event. Self-immolation is prohibited in Islam (Al-Qaradawi 1994, 327), and indeed it is rare as an act of protest in Muslim countries (unlike, for example, Buddhist ones, cf. Laloë 2004; Rezaeian 2009; Zehn 2014). Additionally, Mohamed Bouazizi, a street vendor, set himself on fire after an alleged offence by a female government officer (who always denied the fact); both the alleged offence and the whole reaction by a street vendor with no known political experience whatsoever gave the whole situation a feeling of excess. This excess needed an interpretation. What would a street vendor give his life for? Bouazizi's claims were never clear, his political opposition was vague, even his personal biography was uncertain ${ }^{8}$ (rumours that he was an unemployed university graduate circulated during the first days after the event, as if to interpret his tragedy as the social situation of his generation). Furthermore, the fact that there was no video coverage of such an event might have given the whole situation an aura of sanctity. We only need to remember that, traditionally, Islam art prohibits representation (cf. Nasr 1987, 195ff), and a widely disseminated event without a clear representation could provide an echo of that tradi-

\footnotetext{
${ }^{7}$ A chronicle of the events at the time of their occurrence can be found in Rifai 2011.

${ }^{8}$ For an example of these and other concerns, see Davies 2011.
} 
tion. In a certain sense, cultural image interpretations rely on comparisons, contrasts, and on the heuristics of the question-answer structure of practical understanding (Gadamer 1993/1979, 331-338; Müller 2012, 141-153). Therefore, just as museuminfluenced (even if elitist) image coding still plays an important role in Western societies (Müller and Raab 2014, 198), this specific widely acknowledged cultural trait from Islam should be taken as a latent source for its background context interpretation.

In any case, the unexplained demanded an urgent interpretation, and many generalisations structured it altogether as the allegory of injustice - especially against the youth - under the Ben Ali regime.

2. The need to account for Bouazizi's excessive reaction brought a general commotion. Visual analogies and critical comments began to appear and they disseminated rapidly. ${ }^{9}$ In some sense the news report itself could have constituted the people's desire to transmit an event they considered important, because of its semantic overload (even if there was no picture of the self-immolation, the mental image itself, the imagined and represented depiction of the horrific act, could only be explained by a deep shared despair ${ }^{10}$ ). Bouazizi's decision had been impulsive, but people could think, empathise or project themselves onto a thousand common causes that might have sparked it. Social background came to the fore as an ineludible context. And people kept transmitting secondary events of protest, where all this commotion took on different shapes: therefore, they became political per se: visual materials depicting acts which meant to expose, relate and articulate claims and demands. Unlike other Arab countries where the use of the image within the political field had been a recent tendency (Lebanon, Iran, Egypt), Tunisia experienced, for the first time, an awakening of sorts, a catalysis, an "image hysteria", to use Azza El-Hassan's description. ${ }^{11}$ Taking a picture of something unthinkable before - a street protest - was now a common way of 'acting' against the political establishment.

3. The attempt by the government to get hold of the situation only contributed to demonstrate its feebleness. The turmoil brought about by the event caught the attention of the dictator Zine El Abidine Ben Ali, who on 28 December visited Bouazizi in hospital. The mediality of the visit was completely controlled, almost staged, and a single photo of it was distributed (besides a video that was aired on a news channel but whose reach did not extend as far as that of the image; see Chapter 3). In any case, Bouazizi did not survive long after it, and died on 4 January, only six days after

${ }^{9}$ See e.g. one widely-shared depiction of Bouazizi's self-immolation here [June 2017].

${ }^{10}$ In political protests, it is usually the case that when a confrontation between a disproportionately strong authority and a single individual is translated into an image or a narrative, it becomes almost immediately a symbol of oppression that works affectively, as a solidarity bond, upon the oppressed. Many examples abound, and most of them are analogous to the mythical model of the Biblical narrative of David and Goliath. But Bouazizi's case belongs to yet another subcategory of social agitation, brought about by events lacking an image. Two other exemplars are the social uprisings in India in December 2012 that developed after the gang-rape and death of a 23-year-old woman in Delhi (BBC 2012a), which started a nation-wide movement against machismo; and the political turmoil that shook the Ukraine after the rape and brutal murder of Oksana Makar (BBC 2012b), involving the offspring of political elite members. In both cases, accounts of events of brutal excess omitted any images, mainly due to their explicit sexual content. A comprehensive analysis of such cases, exploring the lack of images on rape attacks and their social consequences, is developed by Azoulay $(2008,217 \mathrm{ff}$.). Bouazizi's case comes close to this rationale.

${ }^{11}$ Quoted in Khatib $(2013,162)$. 
Ben Ali's visit. The metaphor of the dictator's powerlessness was complete, but the government insisted on the narrative of control. Even if there was no video material documenting Bouazizi's self-immolation, the government began prohibiting the materials produced by other citizens, especially during his burial and other protest events. This edict further enraged the Tunisian people, who had become by then spectators of their own mediatic forces, now unleashed. The government would not stand even ten more days, and collapsed on January 14, 2011. After 24 years in power, the dictator was finally ousted and exiled himself to Saudi Arabia.

\section{Ben Ali and the Hospital Visit: Moving in the Footsteps of a Visual Political Genre}

Professional politicians have always been aware of the importance of images and the role they play in political processes. While in former times images were mediated through different technical means ${ }^{12}$ - oil paintings, architecture, busts, or even visual allegories such as Hobbes' Leviathan or Machiavelli's Prince - today it seems that the New Media is provoking a new demand for visual material. Politicians and their staff usually follow a more or less professionalised media strategy. One of the most refined and channelled approaches was to be found in the US's White House, under Barack Obama's "image machine" (Fournier 2013), which had been criticized for being more restrictive than during previous American presidencies (Soave 2013; Cilizza 2012). ${ }^{13}$

It is striking how differently politicians and their communication staff-members deal with the requirements of an image-driven public. This becomes obvious when comparing the visual material that is produced during the hospital visits of different political leaders. Hospital visits appear to be part of the core of political rituals that often produce visual material to be circulated after the fact.

Pictures of politicians visiting patients in hospitals are nothing new in the political sphere. ${ }^{14}$ Whereas these visits are meant to produce a certain statement when facing national disaster and distress, they have to deal with the always-threatening public assumption/suspicion of not being 'honest' or 'true', and using tragic incidents for their own agenda. This was the minefield into which Ben Ali was entering when he visited the hospital on 28 December 2010. The impact of his visit was intensified by the growing protest movement that evolved after Bouazizi's self-immolation. One particular picture was handed out afterwards and was widely distributed throughout the national and international media (including CNN (CNN Arabic Staff 2011), and it is very likely still the first one to appear in Google's image search when using the search term 'Ben Ali Bouazizi'. But it did not really work the way Ben Ali may have

\footnotetext{
${ }^{12}$ Mostly researched within the program of a "political iconography", embedded within the art history (Warnke et al. 2011).

${ }^{13}$ Official pictures during the Obama administration were mainly being produced and distributed by the White House's now archived Flickr account (to be found at https://www.flickr.com/photos/obamawhitehouse/). The White House maintains its own Photo Office, with the chief photographer under Obama being Pete Souza, sometimes referred to as "Obama's secret weapon" (see Cilizza 2012). At the same time, access to the White House by independent photographers was restricted during this period, which lead to harsh criticism (see Fournier 2013; Soave 2013).

${ }^{14}$ Obama had himself photographed at hospitals, e.g. after the Arizona shooting, to be found here [June 2017]. If you compare images from Kim Yong-Un, Angela Merkel, David Cameron, Bashar Al-Assad and Enrique Pena Nieto, you can notice very different visual interpretations, or styles of the 'hospital visit' (all sourced June 2017).
} 
planned, since the picture was interpreted in a way that only weakened his already precarious position. It was perceived as a desperate attempt to depict himself as the caring father of the nation, and at the same time he was perceived as the one responsible for the circumstances that led to Bouazizi's desperate act.

The long path the picture took left the present authors wondering what elements of the picture and its context had enabled this route of interpretation. To reconstruct the social meaning of the picture and make it more comprehensible, its intrinsic logic has to be taken into account. The documentary method offers a very stringent approach to the reconstruction of not subjective, but rather collectively shared knowledge and the actors' habitus ${ }^{15}$. It was applied here to allow a deeper analysis of the picture's effects and interpretation.

\subsection{The Documentary Method of Image Analysis}

It was mainly the German sociologist Ralf Bohnsack who adapted Imdahl and Panofsky's iconic approach to social scientific analysis, while at the same time maintaining a methodologically stringent approach to a social theory - heavily drawing on the German sociologist Karl Mannheim - in order to develop an instrument that takes into account the specificity of the visual and the "importance of pictures or images for practical action, their quality and capacity to provide orientation for our actions and our everyday practice" (Bohnsack 2009, 298). The main aspect of the analysing process is a general shift in perspective: to ask for the "how" (the implicit knowledge) rather than the "what" (the explicit knowledge an image represents; Bohnsack 2009, 299-300). This is mirrored in the differentiation between the recognising and seeing approaches of the act of seeing - the former referring to what the image pictures (recognition of objects from the material world), and the latter to the image picturing itself, in its own formal structure as a picture. This two-dimensional character expresses itself uniquely in pictures (initially proposed by the art historian Max Imdahl; Bohnsack 2009, 275) and that is why the formal structure and arrangement, its planimetric composition, is one of the most important steps for analysis: it reveals a specific style that transcends the image's intentional meaning (the act of production of 'reality') in contrast to its meaning for the perceived objective reality of the recipients.

In the following, we will take a closer look at the picture of Ben Ali in the hospital (see CNN Arabic Staff 2011), and we will be following the steps for interpretation as proposed by the documentary method, moving from the 'what' to the 'how', in order to make the implicit meaning that the image carries more comprehensible.

\subsection{Pre-iconographic Interpretation}

In the first step of the pre-iconographic analysis, we identify objects that relate to the material world (Bohnsack 2009, 271), while trying to leave out our contextual knowledge, i.e. to pause our interpretation of the denoted social situation. In this case, that means we recognise the following: most of the front part of the picture (around one

\footnotetext{
15 "As is generally known, Bourdieu adopted this concept from Panofsky. The conception of habitus can refer to individuals or to collective phenomena like milieus: for instance to the 'proletarian' or the 'bourgeois' habitus. It may be the expression of a phase of contemporary history or of a specific generation: for instance the habitus of the '68-generation.' Or it may be understood - as it was in the original intention of Panofsky - as the expression of a historical epoch in general: for example of the Gothic or the Renaissance period" (Bohnsack 2009, 272).
} 
fourth of the lower part) shows a white-red plaid blanket, with a person on the righthand side covered in bandages of different white tones, where only what seems to be the mouth is still visible. Tubes of different colours go in between the teeth. The blanket covers the person up to the chest; the left arm (which is also covered by bandages) lies on the blanket. The upper body is lifted, supported by the bed, which is arranged at a 120-degree angle. Where the blanket ends, a purple sheet is visible; on top of the bed a red sheet - which lies under the purple one - can be seen. Over the bed, on the wall, there is a small apparatus to which tubes (of the same colours as those going into the person's mouth - white, yellow and black) are connected on the top and side. Besides the bed, one sees a metal stand, and to its side - on the left - a monitor, on top of a white apparatus, out of which tubes also protrude (and terminate on the chest of the bandage-covered body).

On one third of the picture - the left-upper part - we see a group of figures. On the very left stands a black-haired man with a moustache and a white coat, his hands behind his back (and out of shot), looking at the person on the bed, his mouth slightly open. In front of him is a microphone. The second person from the left is a man with black hair, in a black, shiny suit and a silver tie, looking earnestly at the person on the bed, with his mouth also slightly open. He wears glasses, and his hands are crossed in front of his stomach. Behind him we see the face of another man, also looking towards the bed. In a diagonal behind the man in a black suit, another man stands in a sand-coloured suit with a yellow tie patterned with dark objects. He also wears glasses and stands in the same pose as the man beside him, his mouth closed. Behind that person, one sees others: a group of people that stands behind a glass wall; one person in the very back, with glasses, is turning his head to look inside the room. Another face, with a green surgical mask and white hair cover, is also distinguishable.

Inside the room, three persons in green-greyish hospital scrubs are also in the scene; one woman in front, two men in the back. All have their arms folded. On the woman's arms one sees a blue sweater under the scrubs. The men have white haircovers; the woman wears a blue one, as well as dark glasses. Only the man to the right wears a surgical mask; the others have them hanging around their necks. The heads of these three are directed towards the man in the black suit. While the woman seems to look down at this man's hands, the two men on the right are instead looking at his face. One half of the very back of the room constitutes a window front with blue frames; the rest is a plain white wall.

\subsection{Iconographic Analysis}

When moving to the iconographic analysis of the picture, we can activate our practical and explicit knowledge (Bohnsack 2009, 271), which allows us to recognise the scene as a specific social context, namely a hospital visit: the person in bed is in a very bad condition ${ }^{16}$; the persons with suits are the visitors. The persons with surgical masks and green shirts are the doctors, who are listening to and watching the visitors. The apparatuses, the bed, the tubes, the monitor, and the metal stand serve as typical hospital equipment. Contrary to an everyday life scene from a hospital, this one seems clearly overcrowded: it is an important visit. There are many doctors in place; the use of a microphone hints to the mediatic importance of the visit as well. President Ben Ali is the man in front, in a very thoughtful, serious position, and abso-

${ }^{16}$ Even the association of a mummy comes up: see also Arab American National Museum (2013). 
lutely concentrated on Bouazizi, the man lying on the bed. We are rather familiar with Ben Ali's posture itself: it recalls that of prayer (as in a church, in a mosque, in a synagogue). The doctor on the left appears to be the chief of physicians, as he not only wears a white rather than green coat, but is also the one speaking to the microphone. It seems as if he is explaining Bouazizi's condition to the others. The doctor is the only active person, the only person that does any more than stand by and watch.

\subsection{Planimetric Composition and Perspective (Iconic Analysis)}

The next step of analysis concerns the iconic level and the formal or geometric structure of the image. The planimetric composition is especially important in this regard, since it refers to the image as a two-dimensional entity (Bohnsack 2009, 278) that can be analysed by identifying the so-called "field lines" structuring the image, pictured in Figure 1. More than one third of the picture is occupied by Bouazizi and his bed. Another third (the upper left) is taken up by the rest of the actors on the scene, which gives this part of the image a sense of density and tightness. Within the group of persons, we can see Ben Ali as the most important; he is framed by the doctors, whereas Bouazizi is located in a distant position. The heads of the persons standing in the room mark another field line, so that the horizontal structure is parallel and simple.

The planimetric composition reveals a clear antagonism between Bouazizi (whose body takes even less than a third of the picture, since almost half of the area accommodates only the blanket) and the rest of the persons pictured. Also, the vanishing point can be found in the left part of the picture, exactly over the face of one doctor in the back and in the middle of the group of persons located in the crowded part of the picture, distancing Bouazizi even more from the others (Figure 2).

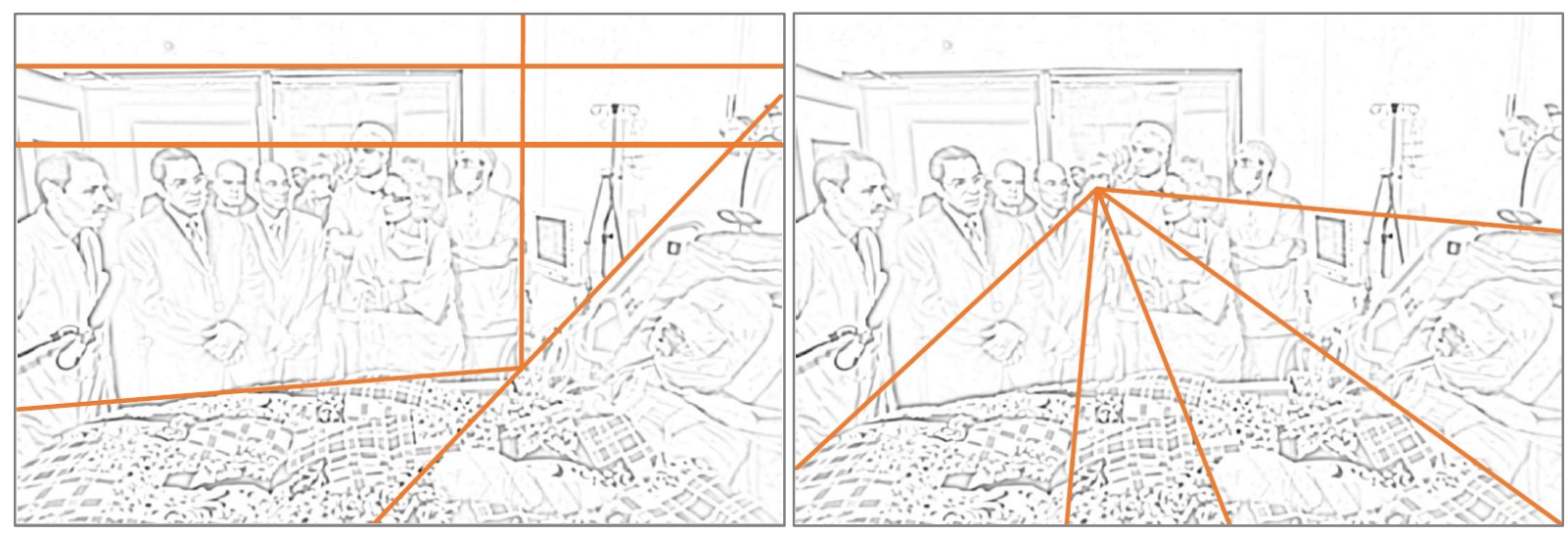

Figures 1 (left) and 2 (right): Planimetric composition (1) and perspective (2)

\subsection{Scenic Choreography (Iconic Analysis)}

While the planimetric composition makes it clear that Bouazizi is separated from the rest of the group (which is not even standing very close to the bed ${ }^{17}$ ), the analysis of the scenic choreography, which refers to the spatial arrangement of objects and persons pictured, hints to another aspect of antagonism. Ben Ali and his two attendants are framed by the doctors - the doctor in white on the left (the only one standing a bit closer to the bed) and the three in green on the right, who are looking at a different

\footnotetext{
17 This becomes more obvious when compared to the other pictures (see Footnote 15) where the visitors stand often very close by the patient.
} 
direction to the persons standing on the left; they are looking at Ben Ali. They are also the ones standing closest to Bouazizi. With their view towards Ben Ali as well as with their folded arms (usually seen as a distancing gesture), they appear to be asking - and waiting. It is noteworthy that there is a contrast found on this level regarding their ages, which span between youth and seniority. While the young doctors on the right are looking to the left, the older men on the left side of the picture (including the oldest doctor to be seen in the picture) stare at Bouazizi's figure. The rest of the 'crowd', mostly younger people as far as it can be recognised, are in the back, even on the other side of the glass window.

\subsection{Iconologic-Iconic Interpretation}

Altogether, the picture conveys passiveness, especially when compared to other 'hospital visit' images (see Footnote 15). Everything stands still while Ben Ali is watching - only the doctor on the left is active, explaining something to Ben Ali. He is the specialist at work: Ben Ali lets him work and does not interfere; he is listening. At the same time, he is causing an interference: the doctors are pausing because of him, and he is the one responsible for the situation - without his visit the doctors would be working. Ben Ali is in the very centre of the picture as he is surrounded by doctors who are either speaking to or looking at him. Even if they were interrupted, and turned passive for a moment, they show at the same time an inherent activity: the almost aggressive position of arms - crossed, as if locking themselves up; their strong look at Ben Ali. They are also the young doctors, standing their ground 'against' the establishment.

Bouazizi is lying in front and takes more space in the picture than anyone else; at the same time he appears to be the least important element of the picture (this is even reinforced by the fact that the light is concentrated on the group of people; Bouazizi lies in shadow, and also in the foremost plane, whose focus is not all too sharp). Nothing hints as to whether he is still a living human being, and the prayer posture of Ben Ali and his attendants further strengthens this interpretation. The image lives off this inherent dualism of activeness and passiveness.

This contrast is made possible by "Übergegensätzlichkeit" (trans-contrariness) as an important aspect of the iconic logic (Bohnsack 2009, 278). It evolves due to the simultaneity inherent to images and their complex semantic structure. In the case discussed here, the image appeared in a political situation where the whole discourse was evolving around the very question of who was to blame, what actor was leading to Tunisia's weak socio-economic and political situation. Therefore, it is perhaps no surprise that this picture fitted so well into the protesters' narrative - Ben Ali may have tried to appear passive, as an affected and affectionate person, but the picture reveals quite the opposite; which becomes even more obvious when comparing this image to images of hospital visits by other politicians. It was very likely that this semantic tension and pragmatic contradiction could lead to the broader reception of this image - opposite to the intention of the regime - and can partly explain why it was so widely shared.

\section{Summary: Making Sense out of a Political Image}

Images have been historically important for an effective and symbolic political communication, but technology has made possible a new infrastructure and dynamic where pictures and moving images have become central pieces of information that are able to articulate new social interactions. As social platforms, Facebook and Twitter have certainly not been triggers of revolutions per se, but they have been articu- 
lating stages - the tip of the iceberg, or the perceived front line - of communication networks where agents with relatively low technical skills can easily participate on varying levels of political engagement. If we understand a medium as something beyond the material infrastructure and the logical system that makes it work, and closer to a social practice made up of skills, habits, techniques, tools, codes and conventions (as does Mitchell 2008, 3, following Williams 1977, 158-64) we have witnessed the emergence of a different, unstable (maybe unstabilisable?) medium: the so-called social media. Since users have discovered they are a very important component in this circuit of flows, the medium itself will certainly continue to morph, develop and perform over different technical platforms, acquiring unexpected expressions in the near future. In the meantime, developing over this dynamic, meanings also shift as unexpectedly and rapidly as the medium that conveys them.

When the meaning of visual material was enabled and politically enacted by a critical mass of engaged users in Tunisia in early 2011, this came with a dramatic effect for the re-connotation of a social and well-known context. This semiotic reinterpretation opened a window for social mobilisation: a familiar circumstance became unbearable, as well as the most evident sign for an ongoing political oppression. This does not mean that the Tunisian government did not have any experience with the symbolic use of political images. But the emerging social media networks were able to signify visual materials to the protestor's advantage out of a stable and controlled code. In other words, there was an active process of re-constitution of semiological chains, or "visual" semiosis (Barthes 1970/1957, 187; Barthes 1989, 36), a semiotic process where a given meaning (as sign) constitutes itself out of a pre-existing chain (signifier-signified). The re-coded sign of a first chain thus became the signifier of a second chain, in this case with a political encoding. That meant there was a short-span period of reconfiguration of the visual code and meaning along the medium, which the protesters exploited. Images played a role as communicative tools (to inspire, to explain, to persuade, to influence) for mobilising purposes, rather than just being 'referents' on a controlled and official 'reality'. For the people and the protesters, these images were more real than the 'real' of their stabilised social quotidian. In this sense, images actively behaved as pieces of clear, distinct and effective communicative action in the public sphere, just as linguistic arguments (Habermas 1981). Later on, the window of opportunity in which this semiosis was most active was probably no longer there, as the Arab Spring contagion sprang to other countries - i.e. as other governments learned to control technological networks more effectively and downplay the emotiveness of specific visual material ${ }^{18}$ - and that might partially explain their comparative failure.

Now, it is an idle question to think whether another picture would have fit better into the counter-narrative of the 'powerless dictator' - a sort of oxymoron in itself - as well as into the still-relevant narrative of an emerging protest movement taking to the streets against the establishment, the 'caste of old men', so well as this one did. Still, we believe it was worth having a closer look at what exactly this particular image offered to connect to the political events, in order to identify one of the elements that contributed to a politicised audience turning against Ben Ali, who fled the country two

${ }^{18}$ Later on, and without the need for central control, Facebook and Twitter have also - with the use of algorithms that enclose behaviours and interests - turned themselves mostly into technological platforms that bring like-minded people together, as a system of mirrors for isolated individuals, avoiding the necessary contagions from different world-views that would make a wider social mobilisation possible. (See some of these current trends in Modani et al. 2014). 
weeks after the hospital visit. The analysis of the picture does not aim at offering a decisive explanation of those events, but rather at unfolding the communicative potentialities of this image, its elements referring to a socially shared knowledge, in order to criss-cross the semiotic operations with the political actions and bring them to a further reflection. The picture carried a symbolic dualism - power against impotence, youth against age - that can be found on different levels of its visual structure. And while, of course, it cannot be by itself the main reason for Ben Ali's fall, the communicative innuendos, as decoded almost oppositely by the establishment apparatus and the new practices brought about by telecommunication technologies, it surely contributed to confirm and perform on a growing idiosyncratic gap. The dictatorship was no longer on the side of its people. It does not seem a coincidence that, in the midst of a propagandistic warfare between two sides, it was this particular picture - produced by the political structure with an opposite objective to that which it ended up serving - that became so well-known.

\section{References}

Allan, Stuart. 2009. Citizen Journalism: Global Perspectives. New York: Peter Lang.

Al-Qaradawi, Yusuf. 1994. The Lawful and the Prohibited in Islam. Plainfield: American Trust Publications.

Arab American National Museum. 2013. Photographic Truth-Claims. Accessed March 11, 2016. http://artsofthearabworlduprisings.com/photographic-truth-claims

Arendt, Hannah. 1997. ¿Qué es la política? Translated by Rosa Sala Carbó. Barcelona: Paidós.

Arendt, Hannah. 1990/1963. On Revolutions. London: Penguin.

Azoulay, Ariella. 2008. The Civil Contract of Photography. New York: Zone Books.

Banash, David C. 1999. The Blair Witch Project: Technology, Repression, and the Evisceration of Mimesis. Postmodern Culture 10(1). Accessed June 8, 2016. https://muse.jhu.edu/article/41932

Barthes, Roland. 1970/1957. Mythologies. Paris: Éditions du Seuil.

Barthes, Roland. 1989. Sade Fourier Loyola. Translated by Richard Miller. Berkeley, CA: University of California Press.

BBC News. 2012a. Protests in India after Delhi Gang-Rape Victim Dies, 29 September. Accessed September 29, 2016. http://www.bbc.com/news/world-asia-india-20863707

BBC News. 2012b. Ukraine Rape Scandal Victim Oksana Makar Dies, 29 March. Accessed November 6, 2016. http://www.bbc.com/news/world-europe-17546743

Bohnsack, Ralf. 2009. The Interpretation of Pictures and the Documentary Method. In Qualitative Analysis and Documentary Method in International Educational Research, edited by Ralf Bohnsack, Nicole Pfaff and Wivian Weller, 267-292. Opladen: Barbara Budrich.

Budmar, Patrick 2012. Why Japanese Smartphones Never Went Global. PC World, 11 June. Accessed June 7, 2016.

https://www.pcworld.idg.com.au/article/430254/why japanese smartphones never went global/

Cardoso Pereira, Paula and Joaquín Zerené Harcha. 2014. Revolutions of Resolution: About the Fluxes of Poor Images in Visual Capitalism. tripleC: Communication, Capitalism \& Critique. Open Access Journal for a Global Sustainable Information Society. 12(1): 315-327.

Cilizza, Chris. 2012. How Pete Souza became President Obama's Secret Weapon. The Washington Post, 19 December. Accessed March 11, 2016.

https://www.washingtonpost.com/news/the-fix/wp/2012/12/19/pete-souza-presidentobamas-secret-weapon.

CNN Arabic Staff. 2011. How a Fruit Seller Caused Revolution in Tunisia. CNN, 16 January. Accessed June 2017.

http://edition.cnn.com/2011/WORLD/africa/01/16/tunisia.fruit.seller.bouazizi/index.html 
Davies, Wyre. 2011. Doubt over Tunisian 'Martyr' who Triggered Revolution. BBC News Tunis, 17 June. Accessed November, 2016. http://www.bbc.com/news/world-middle-east13800493

de Certeau, Michel. 1984. The Practice of Everyday Life. Translated by Steven Rendall. Berkeley, CA: University of California Press.

Deleuze, Gilles. 1992. Postscript on the Societies of Control. October 59: 3-7.

Etling, Bruce, John Kelly, Robert Faris and John Palfrey. 2010. Mapping the Arabic Blogosphere: Politics and Dissent Online. New Media \& Society 12(8): 1225-1243.

Fournier, Ron. 2013. Obama's Image Machine: Monopolistic Propaganda Funded by You. National Journal, 21 November. Accessed March 11, 2016. https://www.nationaljournal.com/white-house/2013/11/21/obamas-image-machinemonopolistic-propaganda-funded-you

Fuchs, Christian. 2014. Social Media: A Critical Introduction. London: Sage.

Fuchs, Christian. 2008. Internet and Society: Social Theory in the Information Age. New York: Routledge.

Fuller, Matthew. 2003. Behind the Blip: Software as Culture. New York: Autonomedia.

Gadamer, Hans-Georg. 1993/1979. Über das Lesen von Bauten und Bildern. Gesammelte Werke 8: 331-338.

Gerbaudo, Paolo. 2012. Tweets and the Streets: Social Media and Contemporary Activism. London: Pluto Press.

Habermas, Jürgen. 1981. Theorie des kommunikativen Handelns. Band 1: Handlungsrationalität und gesellschaftliche Rationalisierung. Frankfurt/Main: Suhrkamp.

Hanke, Bob. 2005. For a Political Economy of Indymedia Practice. Canadian Journal of Communication 30 (1). Accessed September 20, 2016. http://www.cjconline.ca/index.php/journal/article/view/1479/1595

Heidegger, Martin. 1989. Beiträge Zur Philosophie (Vom Ereignis). Edited by FriedrichWilhelm Von Herrmann. Frankfurt: Vittorio Klostermann.

Modani, Natwar, Seema Nagar, Saswata Shannigrahi, Ritesh Gupta, Kuntal Dey, Saurabh Goyal and Amit A. Nanavati. 2014. Like-Minded Communities: Bringing the Familiarity and Similarity Together. World Wide Web 17: 899.

Nasr, Seyyed Hossein. 1987. Islamic Art and Spirituality. Albany: SUNY Press.

Khamis, Sahar and Katherine Vaughn. 2011. Cyberactivism in the Egyptian Revolution: How Civic Engagement and Citizen Journalism Tilted the Balance. Arab Media and Society 14(3): 1-25.

Laloë, Veronique. 2004. Patterns of Deliberate Self-Burning in Various Parts of the World: A review. Burns 30(3): 207-215.

Lucretius. 1963. De Rerum Natura. Edited by Cyril Bailey. Oxford: Oxford University Press.

Müller, Michael R. 2012. Figurative Hermeneutik. Sozialer Sinn 13 (1): 129-161.

Müller, Michael R. and Jürgen Raab. 2014. Die Produktivität der Grenze: Das Einzelbild zwischen Rahmung und Kontext. In Grenzen der Bildinterpretation, edited by Michael R. Müller, Jürgen Raab and Hans-Georg Soeffner, 197-219. Wiesbaden: Springer.

Nichols, James H. 1976. Epicurean Political Philosophy: The De Rerum Natura of Lucretius. New York: Cornell University Press.

Kassim, Saleem. 2012. Twitter Revolution. How the Arab Spring was Helped by Social Media. Policy.mic, 3 July. Accessed September 20, 2016.

https://mic.com/articles/10642/twitter-revolution-how-the-arab-spring-was-helped-bysocial-media\#.gvu1WwUDM

Khatib, Lina. 2013. Image Politics in the Middle East. London: Tauris.

Lasswell, Harold Dwight. 1950. Politics: Who Gets What, When, How. New York: P. Smith.

Lucendo, Santiago. 2010. The Blurred Image. Re-visiones \#0. Accessed September 20,

2016. http://www.re-visiones.net/spip.php\%3Farticle16.html

Mitchell, W.J.T. 2008. Addressing Media. Mediatropes 1: 1-18. 
Morozov, Evgeny. 2012. The Net Delusion: The Dark Side of Internet Freedom. New York: BBS.

Rezaeian, Mohsen. 2009. Islam and Suicide: A Short Personal Communication. OMEGA Journal of Death and Dying 58 (1): 77-85.

Rifai, Ryan. 2011. Timeline: Tunisia's Uprising. Chronicle of Nationwide Demonstrations over the Country's Economic Crisis. Al Jazeera English, 23 January. Accessed November 2016. http://www.aljazeera.com/indepth/spotlight/tunisia/2011/01/201114142223827361.html

Soave, Robbie. 2013. AP editors: Obama relies on staged propaganda photos. The Daily Caller, 11 November. Accessed March 11, 2016. http://dailycaller.com/2013/11/01/apeditors-obama-relies-on-staged-propaganda-photos

Steyerl, Hito. 2009. In Defense of the Poor Image. E-Flux Journal 10 (11): 1-9. Accessed September 20, 2016. http://www.e-flux.com/journal/in-defense-of-the-poor-image/

Strauss, Anselm L. 1979. Social Worlds and Spatial Processes. Working paper. San Francisco: University of California.

Taleb, Nassim Nicholas. 2007. The Black Swan: The Impact of the Highly Improbable. New York: Random House.

The Economist. 2010. Dotty but Dashing, 8 April. Accessed September 20, 2016. http://www.economist.com/node/15865270

Vatter, M. and M. Ruiz Stull. 2011. Política y acontecimiento. Santiago: FCE.

Walker, Rob B. J. 2016/1994. Social Movements/World Politics. In Out of Line: Essays of the Politics of Boundaries and the Limits of Modern Politics, edited by Rob B.J. Walker, 112142. New York: Routledge.

Warnke, Martin, Uwe Fleckner and Hendrik Ziegler, eds. 2011. Handbuch Politische Ikonographie. 2 Bände. München: C.H.Beck.

Williams, Raymond. 1977. Marxism and Literature. New York: Oxford University Press.

Yegulalp, Serdar. 2012. Camera Phones: A Look Back and Forward. Computerworld, 11 May.

Zehn, Rayan. 2014. Why People Commit Self-Immolation: A Study. Accessed September 29, 2016. https://www.youtube.com/watch?v=cgsS6AzBQql

\section{About the Authors}

\section{Giulia Montanari}

Giulia Montanari is a German geographer who has been working in the field of urban studies since 2009. She specialised in qualitative data analysis and the documentary method, which she used in her PhD thesis to explain how we use different notions of space to talk about our everyday family life. She is also interested in visual accounts of knowledge production and has been working on protests and their visuality in the internet since 2014 .

\section{Javier Toscano}

Javier Toscano is a theorist and writer. He holds a PhD in Philosophy and works at the crossroads of social sciences, urbanism, film and artistic practices. He has been awarded post-doc fellowships in Paris (Université de Paris IV-Sorbonne, 2011-2012) and Berlin (FU Berlin, 2014-2016). He is currently a researcher on media studies at the TU Chemnitz in Germany. 